\title{
Reconstruction of sedimentation in Lake Terebenskoye (the Valdai Upland, Russia) in the Late Pleistocene and Holocene
}

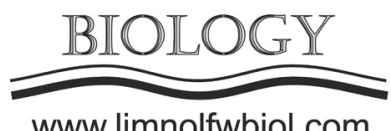

www.limnolfwbiol.com

\author{
Ivanova K.O. ${ }^{1 *}$, Kublitskiy Y.A. ${ }^{1}$, Leontiev P.A. ${ }^{1}$, Brylkin V.V. ${ }^{1}$, Grekov I.M. ${ }^{1}$, \\ Sokolova N.V. ${ }^{1}$, Subetto D.A. ${ }^{1}$, Kuznetsov D.D. ${ }^{2}$, Orlov A.V.
}

${ }^{1}$ Herzen State Pedagogical University of Russia, Nab. Moyki 48, St. Petersburg, 191186, Russia

${ }^{2}$ Institute of Limnology, Russian Academy of Sciences, Sevastyanova str. 9, St. Petersburg, 196105, Russia

\begin{abstract}
The article presents results of analysises the loss on ignition and radiocarbon dating of the bottom sediments of Lake Terebenskoye. Based on the obtained data, a preliminary reconstruction of the sedimentation processes of lakes of the Valdai Upland in the Holocene is constructed. The stages of minerogenic sedimentation in the Older and Younger Dryas and organogenic sedimentation in the Allerød and Preboreal are distinguished.
\end{abstract}

Keywords: lake-bottom sediments, Holocene, paleogeographic reconstruction, Holocene, Valdai upland, Lake Terebenskoe.

\section{Introduction}

The Valdai Upland is very interesting from the point of view of paleogeography because it is located almost on the border of the Late Glacial Maximum (LGM). It was freed from the ice sheet earlier, consequently, the processes of sedimentation on upland started also earlier. This makes it possible to study changes in the natural conditions of earlier periods. Small lakes and Its sedimentation processes are sensitive to environmental changes. In this study, we performed lithological, radiocarbon, and losses on ignition (LOI) analysis for sediment cores taken from Lake Terebenskoye.

\section{Methods}

The research region is located in the northwestern part of the Valdai Upland. The object of study is Lake Terebenskoye ( $58^{\circ} 08$ ' 27.9 ' N $33^{\circ} 00$ ' $04.3^{\prime \prime} \mathrm{E}$, altitude issurface154 meters above sea level). Four points were selected for sampling, with a depth of $206 \mathrm{~cm}, 200 \mathrm{~cm}, 250 \mathrm{~cm}$ and $200 \mathrm{~cm}$. The cores were selected by a Russian peat-corer from the ice. Then a complex lithological description of the columns of bottom sediments was made (color, type of sediment, mineral and organic inclusions). After the description, the samples were photographed and packed in plastic wrap and pipes. About 253 samples were studied in the laboratory using LOI analysis. Radiocarbon analysis for 4 samples was studied in the laboratory of the National Taiwan University - national Taiwan University The samples were prepared by sieving of terrigenous vegetation macrofossils in order to minimize the dating error.

\section{Results and discussion}

Based on the results of the analysis of LOI several zones were identified. Zone $1-674-735 \mathrm{~cm}$ from the water's surfacesurface. This zone of the core is composed of dense dark brown sandy clay. The content of organic matter in this zone is about $1-2 \%$, most likely its formation belongs to the Older Dryas period. An attempt was made to determine the age of the macrofossil from the depth $735 \mathrm{~cm}$ (sample NUAMS$6048 \mathrm{~b}$ ), but the result shows the large error. Zone 2 - 640-674 cm from the water's surface. Organic matter increases at a depth of $667-672$ - up to $40-44 \%$, then decreases to $7-10 \%$. Here there is a sharp change of sedimentation conditions to the organogenic type (the formation of peat). Radiocarbon dating, with a small margin of error (NTUAMS-6051-1) indicates the age of the Allerød (13400-12800 cal. yr. BP). Zone 3 - 600$638 \mathrm{~cm}$ from the water's surface is characterized by transition to the minerogenic type of sedimentation, the content of organic matter is reduced to $3-4 \%$. In the Zone $4-470-600 \mathrm{~cm}$ from the water's surface, the amount of organic matter gradually increases up to $30 \%$. Zone $5(432-470 \mathrm{~cm}$ from the water's surface) characterized by rapid increases of organic matter up to $51 \%$, on the average being $44 \%$. Zone $6-284-432 \mathrm{~cm}$ from the water's surface, the organic content gradually decreases to $42-43 \%$. Zone $7-240-284 \mathrm{~cm}$ from the water's surface, the maximum organic matter content 
in the samples is $67 \%$. Zone $8-202-240 \mathrm{~cm}$ from the water's surface, the organic content is reduced to $53 \%$.

\section{Conclusions}

The bottom sediments of the Terebenskoye lake are particularly interesting for detailed study of environmental conditions during the transition from the late Pleistocene to the Holocene. The first sedimentation stage relate to the Older Dryas period and characterized by minerogenic sedimentation processes. During Allerød interstadial ordanogenic type of sedimentation prevailed. This stage finished about 13000-12800 cal. BP. Decrease of organic matter in the sediments marks the transition to the Younger Dryas - the minerogenic sedimentation prevailed again. The transition to Preboreal is marked by an intensive increase in organic matter at depths of $432-600 \mathrm{~m}$. Reconstruction of sedimentation conditions associated with dynamics of temperature and preciptation changes and could be useful for environment evolution studies.

\section{Acknowledgments}

Research and fieldwork are supported by RFBR project 18-35-00707 mol_a.

\section{References}

Desnenko V.K. 1975. Features of the development of lakes of the Valdai glaciation region in the Holocene. History of lakes in the Holocene. In: Mat-ly IV vsesoyuz. the international Symposium. on the history of lakes. L.: VNIIG, pp. 77-82.

Druzhinina O., Subetto D., Stančikaitè M. et al. 2015. Sediment record from the Kamyshovoe lake : history of vegetation during Late Pleistocene and Early Holocene (Kaliningrad district, Russia). Baltica 28 (2): 121-134.

Kaplin P.A., Yanina T.A. 2010. Methods of paleogeographic reconstructions: Methodological guide. Moscow state University, faculty of Geography, pp. 430.

Kulikova M.A. 2011. Radiocarbon (C14) in the environment and the method of radiocarbon Dating. In: Kulkova M.A.(Ed.). Educational and methodological guide. Saint Petersburg: Herzen state University publishing house, pp. 40.

Strakhov N.M. 1954. Precipitation formation in modern reservoirs. pp. 792.

Subetto D.A. 2009. Bottom deposits of lakes: paleolimnological reconstructions. SPb: publishing house of the Herzen state pedagogical University, pp. 344.

Subetto D.A., Prytkova M.Ya. 2016. Bottom deposits of different types of reservoirs. Study method. Petrozavodsk: Karelian scientific center of the Russian Academy of Sciences, pp. 89. 